\section{Outcome of children with ESBL-E. coli acute pyelonephritis treated with cephalosporins}

\section{Dear Editor,}

We read with interest the recent publication by Moxon and Paulus, outlining the management of infections with Enterobacteriaceae producing extended-spectrum beta-lactamase (ESBL). ${ }^{1}$ Treatment options for pediatric ESBL infections often remain limited to carbapenems. We present evidence for the successful use of cephalosporins in the treatment of pediatric acute pyelonephritis caused by ESBL-producing E. coli (ESBL-APN). In addition, we report for the first time successful oral treatment of ESBL-APN with the first generation cephalosporins.

This retrospective study was conducted at the tertiary Children's Hospital, Helsinki University Hospital, Finland and was approved by the Institutional Research Board. We used microbiological surveillance system and detected 136 patients aged 0-18.0 years with urine cultures positive for ESBLEnterobacteriaceae during 1.1.2007-31.12.2016. Of them, we selected only children with APN into subsequent analysis $(n=37)$. We defined APN as a combination of fever, pyuria $>50 \times 10^{*} 6 / 1$, bacteriuria, abnormal C-reactive protein (CRP) and no signs of other focus of infection. We then excluded three individuals who had received empirical meropenem, ciprofloxacin and piperacillintazobactam. The study group thus consisted of 34 patients (13 boys, 21 girls; median age 1.0 years, range $0.1-9.0$ years).

All urine samples were obtained for culture at the hospital and collected into BD Vacutainer ${ }^{\circledR}$ Preservative tubes (Becton Dickinson and Company, Franklin Lakes, New Jersey, USA). Urine samples were collected from either urine bags $(n=17)$ or voided midstream $(n=17)$, and in most children $(71 \%, 24 / 34)$ two subsequent samples were obtained prior to commencement of antibacterials. Standard urine culture was performed. E. coli was detected in urine samples of all children, and one patient was co-infected with nonESBL Klebsiella pneumonia. All blood cultures remained negative. Antimicrobial susceptibility categorization was done by disc testing (Oxoid, Cambridge, UK) according to the EUCAST methodology and clinical breakpoints for SIR interpretation (www.eucast.org). Of the tested E. coli isolates, 100\% (34/34) demonstrated susceptibility to carbapenems and to fosfomycin (19/19), 94\% (32/34) to nitrofurantoin, $88 \%(29 / 33)$ to netilmycin, $64 \%(21 / 33)$ to tobramycin, $63 \%(17 / 27)$ to ciprofloxacin and 29\% (10/34) to trimethoprimsulfamethoxazole. The ESBL production was confirmed with a combination disc test according to the manufacturer (Mast Group, Bootle, UK).

Abbreviations: CRP, C-reactive protein; ESBL, extended-spectrum beta-lactamase; ESBL-APN, acute pyelonephritis caused by ESBL-producing bacteria; i/v, intravenous $\mathrm{SD}$, standard deviation; UTI, urinary tract infections.
The majority of children $(79 \%, 27 / 34)$ presented with the firsttime UTI and had no co-morbidities and no abnormalities on urinary tract ultrasound. Others had a documented history of previous UTI $(n=4)$, structural abnormalities of the urinary tract $(n=3)$, kidney transplants $(n=2)$, and neurogenic bladder $(n=1)$.

Fifteen children $(44 \%, 15 / 34)$ were treated as inpatients and their mean duration of hospitalization was 4.3 days (standard deviation (SD) 2.71 days). Initial empiric therapy included oral cefalexin $(n=9,27 \%)$, intravenous $(\mathrm{i} / \mathrm{v})$ cefuroxime $(n=12,35 \%)$ or parenteral ceftriaxone $(n=13,38 \%)$. After the data on antimicrobial susceptibility became available, patients were treated with either oral nitrofurantoin $(n=11)$, carbapenems $(n=7)$, oral trimethoprim-sulfamethoxazole $(n=5)$, oral ciprofloxacin $(n=4)$ or $\mathrm{i} / \mathrm{v}$ netilmycin $(n=2)$. The therapy of five patients was not changed, despite the microbiological resistance data.

The majority of patients $(88 \%, 30 / 34)$ recovered clinically while receiving empiric cephalosporin therapy. Clinical recovery was defined as defeverscence in $\leq 48 \mathrm{~h}$. Of the remaining four patients who defeverced within $72 \mathrm{~h}$, three had their therapy switched according to the microbiological resistance data, while one continued to receive oral cefalexin.

Altogether, two children (6\%) experienced a recurrence caused by ESBL-E. coli, 2 and 4 weeks after the initial ESBL-APN episode. One of them had received ertapenem as the definitive treatment of the initial ESBL-APN episode (first treated empirically with i/v ceftriaxone), while other had been treated with oral cefalexin only. Control urine samples were obtained in 59\% (20/34) of patients from three days to four weeks after the commencement of therapy. Of these 20 samples, 15 tested (75\%) negative and five (25\%) were positive for ESBL-E. coli. However, despite positive cultures, 2 of the 5 samples showed no pyuria and leukocyte counts were low (6-7 cells $\times 10 * 6 / 1)$ in another 2 samples. Seven patients $(64 \%, 7 / 11)$ demonstrated microbiological recovery while still on inappropriate therapy.

Subgroup of children with no co-morbidities. For the 27 children with first-time APN and with no co-morbidities, we selected 27 controls with non-ESBL-APN who were matched for age, gender and the absence of co-morbidities. Supplementary Table 1 presents the comparison of their clinical, laboratory and outcome data, while Fig. 1 demonstrates the rates of clinical and microbiological recovery in patients and controls. Ethnic background differed significantly among patients and controls, as more patients of nonFinnish origin had ESBL-APN $(p=0.001)$. The rate of clinical recovery appeared identical in both groups, which is in conjunction with previous studies. ${ }^{2}$ Recurrences were actually more common in the non-ESBL-APN group (4/27 vs $1 / 27$ in ESBL-APN group). The mean duration of hospitalization was 3.0 days (SD 1.48 days) in patients with ESBL-APN $(n=11)$ and 2.8 (SD 1.14 days) in those with nonESBL-APN $(n=10, p=0.731)$. The kinetics of CRP appeared similar in both groups (see Supplementary Fig. 1). 


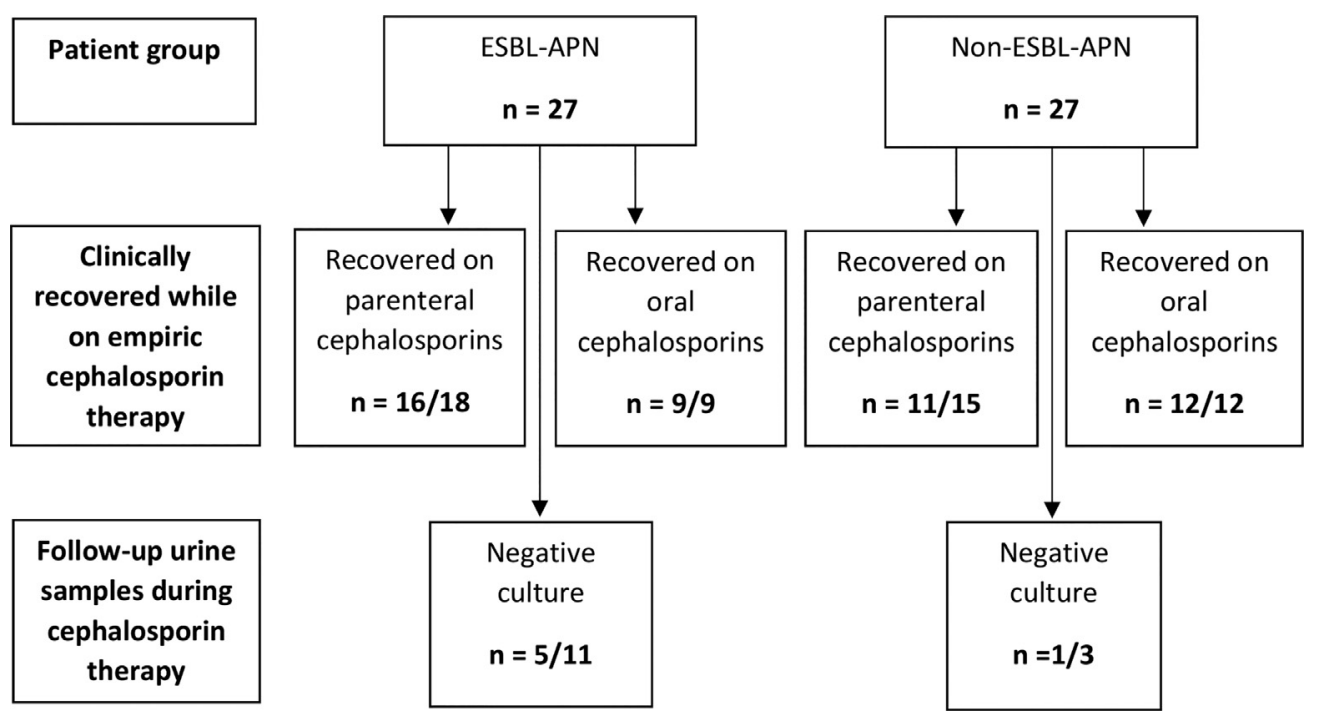

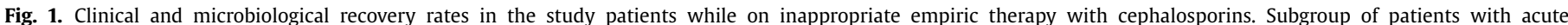

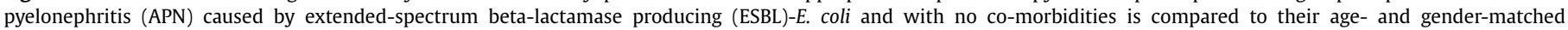
controls with non-ESBL-E. coli APN. ESBL-APN = acute pyelonephritis caused by extended-spectrum b-lactamase producing $E$. coli; $n=$ number.

The good response to cephalosporins in the therapy of ESBLE. coli APN can be partly explained by the high concentration of cephalosporins in urine. ${ }^{3}$ Furthermore, some children with UTI may be able to control the infection spontaneously and recover without proper treatment, as has been shown in some patients with bacterial pneumonia. ${ }^{4}$

We acknowledge that the retrospective nature of our study complicated the appropriate follow-up of the patients. It is possible, but unlikely, that recurrences may have been treated in other hospitals. Further, the relatively small number of patients resulted from the low prevalence of ESBL in Finland. Blood cultures were negative in all our patients, thus our results should not be extrapolated to children with severe bacteremic ESBL-APN. In addition, empiric therapy was changed in many patients after the microbiological susceptibility data became available, thus the definitive therapy may have affected the rate of recurrences.

In conclusion, children with APN caused by ESBL-E. coli showed good response to suboptimal cephalosporin therapy. We do not recommend treating ESBL-APN with cephalosporins, however, if such patients have been cured with this therapy, further parenteral treatment with broad-spectrum antibiotics such as carbapenems may not be necessary.

\section{Funding}

No funding was obtained for this study.

\section{Conflict of Interest}

All authors: no conflicts.

\section{Acknowledgments}

We acknowledge the help of infection control nurse Leena Simons in retrieving data from microbiological surveillance system.

\section{Supplementary materials}

Supplementary material associated with this article can be found, in the online version, at doi:10.1016/j.jinf.2018.03.009.

\section{References}

1. Moxon CA, Paulus S Beta-lactamases in Enterobacteriaceae infections in children. J Infect 2016;5(72 Suppl):S41-9. doi:10.1016/j.jinf.2016.04.021.

2. Tratselas A, Elosifidis E, Ioannidou M, Saoulidis S, Kollios K, Antachopoulos C, et al. Outcome of urinary tract infections caused by extended spectrum b-lactamase-producing Enterobacteriaceae in children. Pediatr Infect Dis $J$ 2011;30(8):707-10.

3. Bundtzen RW, Toothaker RD, Nielson OS, Madsen PO, Welling PG, Craig WA Pharmacokinetics of cefuroxime in normal and impaired renal function: comparison of high-pressure liquid chromatography and microbiological assays. Antimicrob Agents Chemother 1981;19:443-9.

4. Hazir T, Nisar YB, Abbasi S, Ashraf YP, Khurshid J, Tariq $\mathrm{P}$ et al Comparison of oral amoxicillin with placebo for the treatment of world health organizationdefined nonsevere pneumonia in children aged 2-59 months: a multicenter, double-blind, randomized, placebo-controlled trial in Pakistan. Clin Infect Dis 2011;52(3):293-300

Svetlana Vakkilainen*

Children's Hospital, University of Helsinki and Helsinki University Hospital, Stenbäckinkatu 11, PL 281, 00029 HUS, Helsinki, Finland

Anu Pätäri-Sampo

Department of Clinical Microbiology, University of Helsinki and Helsinki University Hospital, HUSLAB, Helsinki, Finland

Harri Saxén

Children's Hospital, University of Helsinki and Helsinki University Hospital, Stenbäckinkatu 11, PL 281, 00029 HUS, Helsinki, Finland

*Corresponding author. E-mail addresses: svetlanakostjukovitch@gmail.com, svetlana.kostjukovits@helsinki.fi (S. Vakkilainen), anu.patari-sampo@hus.fi (A. Pätäri-Sampo), harri.saxen @hus.fi (H. Saxén)

Accepted 17 March 2018 Available online 7 May 2018

https://doi.org/10.1016/j.jinf.2018.03.009

(C) 2018 The British Infection Association. Published by Elsevier Ltd. All rights reserved. 


\section{Leprosy in the Pisan fresco "Triumph of Death" (1336-1341)}

In current times leprosy is a disease widespread especially in the tropical and sub-tropical environments of developing countries $^{1}$, where it still represents a relevant public health problem. However, in the past this disease also involved the European territory. During the $12-14$ th centuries, leprosy had a remarkable diffusion in the Western World at the time of Crusades. The large number of leprosaria founded almost all over Europe, and the osteoarchaeological cases of leprosy, are eloquent evidences of the well-established presence of the disease in late Medieval Europe. ${ }^{2}$ Although leprosy is characterised by a low grade of infectivity, in Medieval collective imagery its deforming impact on the body raised terror and repugnance towards the patients affected. Lepers were a sort of living dead, considered unclean or morally corrupt by Medieval society. They had to wear special clothes, to carry a bell announcing their presence, and they were segregated in lazar houses outside the urban centres. ${ }^{3}$

Leprosy, or Hansen's disease, is a chronic infection caused by Mycobacterium leprae, characterised by involvement of skin, mucous membranes, and nerves. The disease has been classified into a number of clinical types, the most severe of which is its lepromatous form, in which the immune response is poor. Transmission occurs through the airborne spread of nasal secretion.

The organism has a predilection for the cooler parts of the body and, therefore, the most affected regions are the nose and the extremities. The result is deformity of the face with resorption of the nasal cartilage and loss of sensory perception in the fingers and toes. Peripheral anaesthesia can lead to the atrophy of muscle activity with resorption of the tubular bones of hands and feet, which can eventually fall off for secondary infections or involuntary trauma. Lesions can also affect the conjunctivae, causing keratitis, iridocyclitis, up to blindness. ${ }^{4}$

Medieval iconography is not exempt from representations of lepers which, even so, are generally very stereotyped, with the disease simply symbolised through dots spread over the body. ${ }^{5}$ How- ever, a famous Tuscan fresco of the first half of the 14th century offers the first realistic representation of the disease (Fig. 1).

The "Triumph of Death" of the Monumental Cemetery of Pisa, a pictorial masterpiece of Italian Medieval art dated back to the years 1336-1341, is attributed to Buonamico Buffalmacco ${ }^{6}$. In the fresco, which occupies a wall of $5.6 \times 15 \mathrm{~m}$, the author follows a pictorial address characterised by expressionist realism. In the centre of the scene Death, personified in a sort of winged demon with bat wings and sickle, and about to invest a group of wealthy young people on the right, totally ignores a bunch of beggars on the left of the fresco, who invoke her as the liberation of their sorrows. A cartouche, almost a comic, gives voice to the group of beggars, who thus reproach the Grim Reaper: "As prosperity has left us, oh Death, medicine of all evil, come and give us the last supper".

Among the group of beggars who invoke death as extreme consolation to their disasters, the figure of a leper is clearly defined, appearing as an individual with the typical Facies leprosa. The man shows atrophy of the nasal region where the nasal cartilage is totally lacking, and probably blindness, since the eye is without the pupil and seems obscured. The upper limbs, stretched towards Death, appear as two stumps totally deprived of the hands at the level of the wrists. Another beggar in the group appears blind, with his eyes covered by a bandage, and his right hand reduced to a stump, wrapped in a rag closed by a string at the wrist. It is in both cases the iconographic description of a rather typical and advanced stage of the pathology.

Leprosy constitutes a sort of archetypal disease for the Medieval world; the leper is seen as a shameful being, struck by a disease that is a kind of divine curse. In the case of Pisa, we observe a didascalic representation, like a figurative sermon that fits well with the search for greater realism aimed at impressing the observer: in the fresco the leper is the exemplar model of the sinner. ${ }^{7}$

The remarkable fact that distinguishes the lepers of the cemetery of Pisa is, indeed, the highly realistic style of representation for the first time so accentuated in Western art, as the result of a probably direct observation of the disease, and not a stereotyped figuration, as Medieval art has usually been up to that time.

Abbreviations: CRP, C-reactive protein; ESBL, extended-spectrum beta-lactamase ESBL-APN, acute pyelonephritis caused by ESBL-producing bacteria; i/v, intravenous; SD, standard deviation; UTI, urinary tract infections.

is Funding: None.

站放 Declarations of interest: None

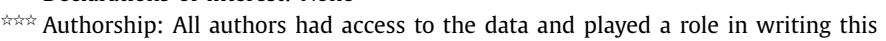
manuscript. 


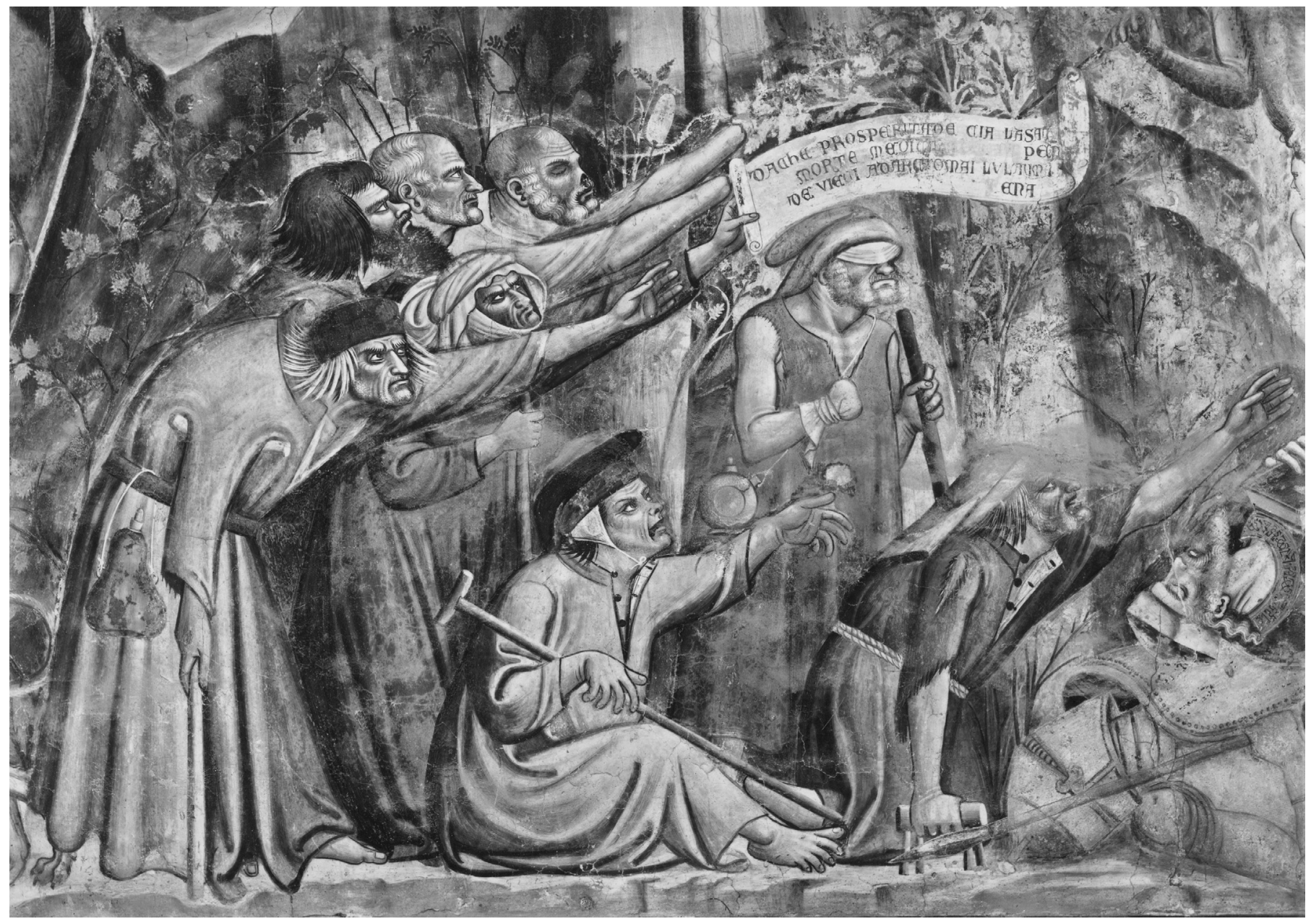

Fig. 1. "The Triumph of Death" of Buonamico Buffalmacco in the Monumetal Cemetery of Pisa (years 1336-1441). Particular of the group of beggars with two lepers [The photographic reproduction is taken from the photo library of the Federico Zeri Foundation].

\section{References}

1. Suzuki K, Akama T, Kawashima A, Yoshihara A, Yotsu RR, Ishii N Current status of leprosy: epidemiology, basic science and clinical perspectives. J Dermatol 2012;39(2):121-9 PMID 21973237. doi:10.1111/j.1346-8138.2011.01370.x.

2. Larsen CS. Bioarchaeology. interpreting behavior from the human skeleton. Cambridge University Press; 2015.

3. Covey HC. People with leprosy (Hansen's disease) during the Middle Ages. Soc Sci J 2001;38:315-21. doi:10.1016/S0362-3319(01)00116-1.

4. Ridley D, Jopling W Classification of leprosy according to immunity. A five-group system. Int J Lepr Other Mycobact Dis 1966;34:255-73.

5. Boeckl CM. Images of leprosy. disease, religion, and politics in European Art. Truman State University Press; 2011

6. Bellosi L. Buffalmacco e il Trionfo della Morte. Torino: Einaudi; 1974

7. Frugoni C. Altri luoghi, cercando il Paradiso (Il ciclo di Buffalmacco nel Camposanto di pisa e la committenza domenicana). Annali della Scuola Normale Superiore di Pisa. Classe di Lettere e Filosofia. Serie III 1988;18(4):1557-643. http://www.jstor.org/stable/24307596.
A. Fornaciari*

R. Gaeta

V. Giuffra

Division of Paleopathology, Department of Translational Research and New Technologies in Medicine and Surgery, University of Pisa, Via Roma 57, 56126 Pisa, Italy *Corresponding author

E-mail address: antoniofornaciari77@gmail.com (A. Fornaciari)

Accepted 5 April 2018

Available online 8 May 2018

https://doi.org/10.1016/j.jinf.2018.04.015

(C) 2018 The British Infection Association. Published by Elsevier Ltd. All rights reserved. 
What is the criterion of 'high' pentraxin-3(PTX-3) cutoff in patients with sepsis?

\section{Dear Editors}

We read with great interest, the recently published metaanalysis by Lee et al., ${ }^{1}$ who concluded that pentraxin-3(PTX-3) significantly predicted disease severity and mortality in sepsis. However, we wish to raise some questions about the study.

First, Lee et al. ${ }^{1}$ aimed to evaluate the predictive value of PTX-3 in the population with sepsis, however, some studies ${ }^{2-4}$ analyzed in the meta included patients who were not septic, the predictive values of PTX-3 from the non-septic population were not separated from the whole population, thus we were afraid that biases may exist and make the final result inaccurate.

Second, Lee et al. ${ }^{1}$ claimed they searched PubMed and EMBASE for eligible studies by using the following terms: [pentraxin-3 mortality sepsis]. However, we are afraid that this search strategy may not be systematic or accurate, some important researches may be missed. For example, one study ${ }^{5}$ investigated the predictive value of PTX-3 in the septic population and could be retrieved in the Pubmed, but it had not been incorporated into the meta-analysis though it should be.

Third, some data in the meta-analysis need to be checked again in Table 1, the unit of following up time should be day rather than month. The sample size of the population with cirrhosis in Fan's study should be $156(48+108)$ rather than 277 , while the sample size of the population with acute kidney injury in critically ill in Schilder's study should be 42 rather than 13, the number of males in Bastrup-Birk's study should be 139 rather than 138, and so on.

Fourth, in Fig. 1 of the meta, the difference in means/median of the study by Huttunen et al. should be 41.5 rather than 38.4 as the latter value was the difference in maximum value between the survivors and non-survivors. In Fig. 2, the lower limit and upper limit of 95\% confidence interval (CI) of hazard ratio (HR) for high PTX-3 levels and risk of mortality in Kim et al.' study should be
$(2.46,15.85)$ rather than $(2.82,18.17)$. Besides, odds ratio (OR) is totally different from hazard ratio (HR), the authors of the meta may mix up the two notions (OR and HR) in the study carried by Wagenaar et al. in Fig. 2.

Fifth, there is no clear definition and limit for "more severe sepsis and less severe sepsis" in the meta-analysis, it can be several different compared groups such as "severe sepsis and sepsis", "septic shock and severe sepsis" and "septic shock and sepsis" which can cause variable results if not specified as two specific groups. Besides, Fig. 2 lists the studies which investigate the relationship between 'high' PTX-3 and risk of mortality. Nevertheless, there are different criterion of 'high' PTX-3 value in different studies in the meta-analysis, varying from $3.35 \mathrm{ng} / \mathrm{ml}^{6}$ to $140 \mathrm{ng} / \mathrm{ml}^{7}$, obviously, 'high' PTX-3 concentration in one study may be deemed as 'low' in others studies, different cutoffs of 'high' PTX-3 should have different predictive value for death, so we suggest the authors provide a unified criterion for 'high' PTX-3 value or just indicate different cutoff of 'high' PTX-3 in each study.

Sixth, systemic levels of PTX3 are well known to be influenced by the age of the patients and underlying disease ${ }^{8}$, as this metaanalysis contains adult and pediatric studies together and infectious diseases in different severity, we strongly suggest the authors carry out subgroup analysis according to the age and the severity of illness.

Finally, we appreciate Lee et al. for their innovative work, but further rigorous validating studies are still needed.

\section{Conflict of interest}

The authors declare that there are no conflicts of interest.

\section{Financial support}

Ye Ye was supported by a grant from the Guangdong Provincial Department of Science and Technology (number: 2015A020210093). The funding sources had no role in the preparation, drafting, review, or approval of the manuscript or the decision to submit it for publication.

Abbreviations: CRP, C-reactive protein; ESBL, extended-spectrum beta-lactamase; ESBL-APN, acute pyelonephritis caused by ESBL-producing bacteria; i/v, intravenous; SD, standard deviation; UTI, urinary tract infections(PTX-3), pentraxin-3; (CI), confidence interval; (HR), hazard ratio; (OR), odds ratio.

i The work of this submission was conducted at the Emergency Department Guangdong Provincial Hospital of Chinese Medicine, Guangzhou, 510120, China. 
Table 1

Characteristics of the nine studies included in this meta-analysis.

\begin{tabular}{|c|c|c|c|c|c|c|c|c|}
\hline $\begin{array}{l}\text { First } \\
\text { author/year }\end{array}$ & Population & $\begin{array}{l}\text { Sample } \\
\text { size }(n)\end{array}$ & Age (yrs) & SD & $\begin{array}{l}\text { No. of } \\
\text { males }\end{array}$ & $\begin{array}{l}\text { Follow-up } \\
\text { (months) }\end{array}$ & Variables in multivariate model & Ref. \\
\hline Jie (2017) & ICU septic shock & 112 & 59 & 20 & 55 & 28 & Multivariate: no parameters provided & 12 \\
\hline Kim (2017) & Sepsis & 83 & 71 & 10 & 47 & 28 & (Univariate) & 13 \\
\hline $\begin{array}{l}\text { Caironi } \\
(2016)\end{array}$ & Severe sepsis & 958 & 70 & 15 & 563 & 90 & $\begin{array}{l}\text { Age, sex, body mass index, reason for ICU admission, SAPS } \\
\text { II and SOFA scores, pre-existing conditions (liver disease, } \\
\text { chronic obstructive pulmonary disease, chronic renal } \\
\text { failure, immunodeficiency, congestive or ischaemic heart } \\
\text { disease), mean arterial pressure, fraction of inspired } \\
\text { oxygen FiO2, diuresis, serum concentrations of lactate, } \\
\text { albumin, bilirubin and creatinine, blood platelets, septic } \\
\text { shock at randomization, mechanical ventilation, antibiotics } \\
\text { at randomization, positive blood culture, plasma } \\
\text { concentrations of presepsin and high-sensitive cardiac } \\
\text { troponin T on day } 1 .\end{array}$ & 8 \\
\hline $\begin{array}{l}\text { Hansen } \\
(2016)\end{array}$ & $\begin{array}{l}\text { Necrotizing soft tissue } \\
\text { infections }\end{array}$ & 135 & 61 & 13 & 84 & 510 & $\begin{array}{l}\text { Age, sex, chronic disease and Simplified acute Physiology } \\
\text { Score II }\end{array}$ & 10 \\
\hline Fan (2016) & Cirrhosis & 277 & 54 & 26 & 139 & 90 & Multivariate: no parameters provided & 9 \\
\hline $\begin{array}{l}\text { Schilder } \\
\text { (2015) }\end{array}$ & $\begin{array}{l}\text { Acute kidney injury in } \\
\text { septicaemia }\end{array}$ & 13 & 70 & 45 & 7 & 30 & (Univariate) & 17 \\
\hline $\begin{array}{l}\text { Elghandour } \\
(2015)\end{array}$ & $\begin{array}{l}\text { Acute leukaemia in } \\
\text { septicaemia }\end{array}$ & 60 & 39 & 7 & 28 & 3 & (Univariate) & \\
\hline Akin (2014) & Neonatal sepsis & 28 & 0.6 & 0.1 & - & - & (Univariate) & 6 \\
\hline $\begin{array}{l}\text { Bastrup- } \\
\text { Birk } \\
(2013)\end{array}$ & Systemic inflammatory & 261 & 63 & 18 & 138 & 873 & Age and sex & 7 \\
\hline $\begin{array}{l}\text { Uusitalo- } \\
\text { Seppälä } \\
(2013)\end{array}$ & Suspected infection & 537 & 64 & 21 & 310 & 365 & $\begin{array}{l}\text { ICU stay, hypotension, use of vasopressors, acute renal } \\
\text { insufficiency, disseminated intravascular coagulation, } \\
\text { decreased Glasgow Coma Scale, need of mechanical } \\
\text { ventilation, severe sepsis, MOF, plasma CRP levels, plasma } \\
\text { procalcitonin levels, white cell count, platelet count }\end{array}$ & 19 \\
\hline Lin $(2013)$ & $\begin{array}{l}\text { Ventilator-associated } \\
\text { pneumonia }\end{array}$ & 136 & 64 & 12 & 80 & 28 & $\begin{array}{l}\text { APACH II score, CPIS, SOFA score, PO2/FiO2, creatinine, } \\
\text { plasma levels of CRP on day of admission }\end{array}$ & 14 \\
\hline $\begin{array}{l}\text { Huttunen } \\
\text { (2011) }\end{array}$ & Bacteraemia & 132 & 62 & 19 & 70 & 30 & Age and sex & 11 \\
\hline $\begin{array}{l}\text { Mauri } \\
(2010)\end{array}$ & $\begin{array}{l}\text { Severe sepsis and } \\
\text { septic shock }\end{array}$ & 90 & 61 & 15 & 56 & 28 & (Univariate) & 15 \\
\hline $\begin{array}{l}\text { Wagenaar } \\
\text { (2009) }\end{array}$ & $\begin{array}{l}\text { Severe leptospirosis } \\
\text { with and without } \\
\text { sepsis }\end{array}$ & 52 & 45 & 17 & 37 & 14 & (Univariate) & 20 \\
\hline $\begin{array}{l}\text { Sprong } \\
(2009)\end{array}$ & $\begin{array}{l}\text { Severe meningococca } \\
\text { disease }\end{array}$ & 26 & 3 & 8 & 14 & 3 & (Univariate) & 18 \\
\hline $\begin{array}{l}\text { Muller } \\
(2001)\end{array}$ & $\begin{array}{l}\text { Critically ill (SIRS, } \\
\text { sepsis, severe sepsis, } \\
\text { septic shock) }\end{array}$ & 101 & - & - & - & 1 & (Univariate) & 16 \\
\hline
\end{tabular}

Mean difference of PTX-3: non-survivors vs. survivors

Study name

\begin{tabular}{|c|c|c|c|c|c|c|c|}
\hline & $\begin{array}{l}\text { Difference } \\
\text { in means }\end{array}$ & $\begin{array}{l}\text { Standard } \\
\text { error }\end{array}$ & Variance & $\begin{array}{l}\text { Lower } \\
\text { limit }\end{array}$ & $\begin{array}{l}\text { Upper } \\
\text { limit }\end{array}$ & Z-Value & p-Value \\
\hline Jie, 2017 & ๓.900 & 6.717 & 45.120 & 50.735 & 77.065 & 9.513 & 0.000 \\
\hline $\mathrm{Km}, 2017$ & 164.900 & 18.846 & 355.184 & 127.962 & 201.838 & 8.750 & 0.000 \\
\hline Carori, 2016 & 45.000 & 7.840 & 61.459 & 29.65 & 6.365 & 5.740 & 0.000 \\
\hline Hansen, 2016 & 139.300 & 23.880 & 570.251 & 92496 & 186104 & 5803 & 0.000 \\
\hline Schilder, 2015 & 7.000 & 15.827 & 250.499 & -24.021 & 38021 & 0.442 & 0.658 \\
\hline Eghandour, 2015 & 3.960 & 0.453 & 0.205 & 3073 & 4.847 & 8750 & 0.000 \\
\hline Akin, 2014 & 12420 & 4.468 & 19.962 & 3603 & 21.177 & 2780 & 0.006 \\
\hline Uusitaloseppaaa, 2013 & 9.000 & 2026 & 4.107 & 5028 & 12972 & 4.441 & 0.000 \\
\hline Huttunen, 2011 & 38.400 & 4.303 & 18.516 & 29.966 & 46834 & 8924 & 0.000 \\
\hline Mari, 2010 & 18.400 & 68.130 & 4641.640 & -115.132 & 151.932 & 0.270 & 0.787 \\
\hline \multirow[t]{2}{*}{ Wagenaer, 2009} & 25.000 & 16269 & 264.685 & -6.887 & 56887 & 1.537 & 0.124 \\
\hline & 40.334 & 6.796 & 46.190 & 27.013 & 53.654 & 5.905 & 0.000 \\
\hline
\end{tabular}

Difference in means and $95 \% \mathrm{Cl}$

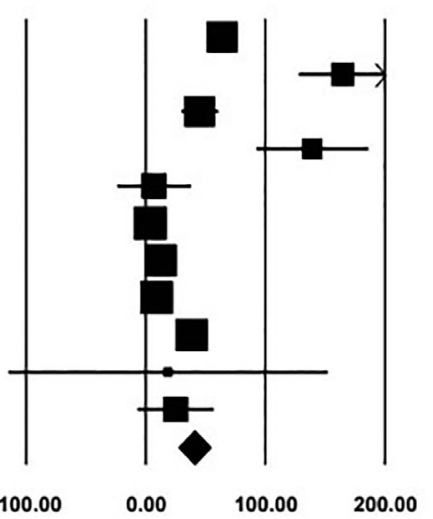

Fig. 1. Mean difference of PTX-3: non-survivors vs. survivors. 
High PTX-3 levels and risk of mortality

Study name
Jie, 2017
Kim, 2017
Caironi, 2016
Hansen, 2016
Fan, 2016
Elghandour, 2015
Akin, 2014
Bastrup-Birk, 2013
Uusitalo-Seppälä, 2013
Huttunen, 2011
Mauri, 2010
Wagenaar, 2009

\begin{tabular}{crrrr}
\multicolumn{6}{c}{$\begin{array}{c}\text { Statistics for each study } \\
\text { Hazard } \\
\text { ratio }\end{array}$} & $\begin{array}{c}\text { Lower } \\
\text { limit }\end{array}$ & \multicolumn{2}{l}{$\begin{array}{l}\text { Upper } \\
\text { limit }\end{array}$} & z-Value & p-Value \\
3.870 & 1.680 & 8.915 & 3.178 & 0.001 \\
7.160 & 2.821 & 18.174 & 4.142 & 0.000 \\
1.130 & 1.012 & 1.262 & 2.166 & 0.030 \\
1.050 & 0.470 & 2.348 & 0.119 & 0.905 \\
3.520 & 2.432 & 5.095 & 6.668 & 0.000 \\
0.906 & 0.810 & 1.013 & -1.736 & 0.083 \\
9.200 & 1.022 & 82.786 & 1.980 & 0.048 \\
2.430 & 1.253 & 4.712 & 2.628 & 0.009 \\
2.798 & 1.514 & 5.169 & 3.285 & 0.001 \\
7.381 & 3.624 & 15.034 & 5.507 & 0.000 \\
1.037 & 1.012 & 1.063 & 2.897 & 0.004 \\
5.600 & 1.203 & 26.067 & 2.196 & 0.028 \\
1.941 & 1.529 & 2.464 & 5.446 & 0.000
\end{tabular}

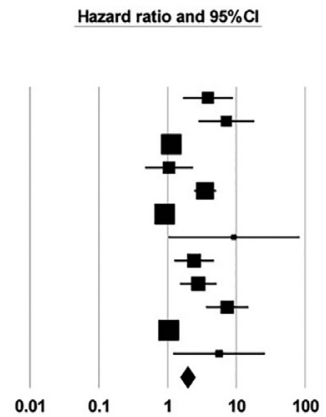

Lower risk

Higher risk

Fig. 2. High PTX-3 levels and risk of mortality.

\section{References}

1. Lee YT, Gong M, Chau A, Wong WT, Bazoukis G, Wong SH, et al. Pentraxin-3 as a marker of sepsis severity and predictor of mortality outcomes: a systematic review and meta-analysis. J Infect 2018;76(1):1-10 PMID: 29174966. doi:10.1016/ j.jinf.2017.10.016.

2. Lin Q, Fu F, Shen L, Zhu B Pentraxin 3 in the assessment of ventilator-associated pneumonia: an early marker of severity. Heart Lung 2013;42(2):139-45 PMID: 23273657. doi:10.1016/j.hrtlng.2012.11.005.

3. Akin MA, Gunes T, Coban D, Ozgun MT, Akgun H, Kurtoglu S Pentraxin 3 concentrations of the mothers with preterm premature rupture of membranes and their neonates, and early neonatal outcome. J Matern Fetal Neonatal Med 2015;28(10):1170-5 PMID: 25048752. doi:10.3109/14767058.2014.947574.
4. Bastrup-Birk S, Skjoedt MO, Munthe-Fog L, Strom JJ, Ma YJ, Garred P Pentraxin-3 serum levels are associated with disease severity and mortality in patients with systemic inflammatory response syndrome. PLoS One 2013;8(9):e73119 PMID: 24039869. doi:10.1371/journal.pone.0073119.

5. Vanska M, Koivula I, Hamalainen S, Pulkki K, Nousiainen T, Jantunen E, et al. High pentraxin 3 level predicts septic shock and bacteremia at the onset of febrile neutropenia after intensive chemotherapy of hematologic patients. Haematologica 2011;96(9):1385-9 PMID: 21880642 P. doi:10.3324/haematol.2011.044925.

6. Elghandour A, Naenaa H, Eldefrawy M, Elbordeny M, Mohammed $\mathrm{H}$ Level of pentraxin-3 in patients with acute leukemia in septicemia and its prognostic value. Int Blood Res Rev 2015;4(1):1-7 PMID: Not found. doi:10.9734/IBRR/2015/ 17737.

7. Kim SB, Lee $\mathrm{KH}$, Lee JU, Ann HW, Ahn JY, Jeon YD, et al. Long pentraxin 3 as a predictive marker of mortality in severe septic patients who received successful early goal-directed therapy. Yonsei Med J 2017;58(2):370-9 PMID: 28120568. doi:10.3349/ymj.2017.58.2.370.

8. Liu S, Qu X, Liu F, Wang C Pentraxin 3 as a prognostic biomarker in patients with systemic inflammation or infection. Mediat Inflamm 2014;2014:421429 PMID: 25530683. doi: $10.1155 / 2014 / 421429$.

Xianshi Zhou*

Ye Ye

Guanghua Tang

Department of Emergency, Guangdong Provincial Hospital of Chinese Medicine, 111 Dade Road, Yuexiu District, Guangzhou 510120, China

*Corresponding author. E-mail addresses: 13660638204@163.com (X. Zhou), guanghuatang123@yeah.net (G. Tang)

Accepted 8 April 2018 Available online 17 May 2018

https://doi.org/10.1016/j.jinf.2018.04.014

(c) 2018 The British Infection Association. Published by Elsevier Ltd. All rights reserved. 